\title{
A Comparative Study of Locus of Control in Underachievers and Normal Achievers
}

\author{
Dr. Tarun Deep Kaur ${ }^{1 *}$
}

\section{ABSTRACT}

The current study aimed at estimating a percentage of underachievers in the sample of school students across the city of Chandigarh. It also aimed at studying self efficacy in underachievers in comparison to normal achievers. A sample of 105 students of class tenth, hailing from intact middle class families formed the sample. After initial identification of underachievers, both the groups were compared for the extent of externality. $t$ ratio was found to be highly significant depicting that underachievers are high on the construct of externality.

Keywords: Locus of Control, Life Skills

Underachievement is a pervasive problem that results in a tremendous wastage of human potential, even among our most able students. The ever increasing number of reported suicides by the adolescents in the city itself because of not being able to up to the mark in academics is an indicator of over emphasis on performance. Underachievement is defined as "a discrepancy between a person's intellectual capacity (IQ) and performance on a standardized achievement test” (Mendel and Marcus, 2016). According to Larry Smith (2015), “Academic underachievement is not meeting expectations and academic potential”. Some of the prominent causes of underachievement as concluded by researchers are emotional problems, secondary gains, teacher - student relationship, peer pressure, fear of failure, boredom, creativity and sibling rivalry. Church, M., Elliot \& Gable, S. (2014) characterizes underachievers as falling into eight different types:

$\begin{array}{ll}\text { - } & \text { Rebel } \\ \text { - } & \text { Conformist } \\ \text { - } & \text { Stressed learner } \\ \text { - } & \text { Struggling student } \\ \text { - } & \text { Distracted learner } \\ \text { Bored student }\end{array}$

\footnotetext{
${ }^{1}$ Head, Department of Psychology, G.G.D.S.D. College, Sector-32, Chandigarh, India *Responding Author

(C) 2016, T Kaur; licensee IJIP. This is an Open Access Research distributed under the terms of the Creative Commons Attribution License (http://creativecommons.org/licenses/by/2.0), which permits unrestricted use, distribution, and reproduction in any Medium, provided the original work is properly cited.
} 


\section{A Comparative Study of Locus of Control in Underachievers and Normal Achievers}

- $\quad$ Complacent learner

- $\quad$ Single sided learner

According to Felton and Briggs (2014), "underachievers expect to fail, generally set their goals too high or too low and have an external locus of control”. According to N.Roberts (2016), "Underachievers do not believe that they are in control of their own success and learning by the types of choices they make”.

Life Skills are 'living skills 'or abilities for adaptive and positive behavior that enable individuals to deal effectively with demands and challenges of everyday life. Midgley; Middleton \& Kaplan, A (2013). According to Elliot \& McGregor, H. (2012) Life Skills are set of skills which are necessary for the promotion of psychosocial wellbeing in children. These skills include: decision making, communicating building self esteem, developing relationships, dealing with conflicts, problem solving, self awareness, coping with stress etc. Life skills are 'living skills' or abilities for adaptive and positive behavior that enable individuals to deal effectively with demands and challenges of everyday life (WHO, 2009). According to Jones (2009) "Life skills are sequence of choices affirming psychological life that people make in specific skills areas”.

Life skills are used during every moment of our lives in various situations like choosing friends/ career, making and breaking relationships, understanding one's needs, and interacting with teachers and parents. Life skills, therefore, are the building blocks of one's behavior and need to be learnt well to lead a healthy, meaningful and productive life (Bharath \& Kumar, 2013).

\section{Areas of Life Skills}

Life skills are categorized by various youth and health organization and adolescents' researchers in different ways. Although the exact nature and description of life skills are likely to differ across social and cultural context, WHO (2007) suggested a core set of skills that are integral in promoting general well being. These sets of skills include: coping with emotions, self awareness, empathy, interpersonal relationship, problem solving, decision making, critical thinking, creative thinking, communication, and coping with stress.

\section{- $\quad$ Self esteem}

Self esteem is the "confidence in our ability to think, confidence in our ability to cope with the basic challenges of life and confidence in our right to be successful and happy, the feeling of being worthy, deserving, entitled to assert our needs and wants, achieve our values and enjoy the fruits of our efforts” (Branden, 1999).

\section{- $\quad$ Self efficacy}

Self efficacy is one of the most powerful determinants of behavioral change because it causes people to take that first step towards their goal, it motivates them to make a concerted effort, and it gives them the strength to persist in the face of adversity. It refers to the confidence in once ability to behave in such a way or to produce a desirable outcome (Bandura, 1977). Self 


\section{A Comparative Study of Locus of Control in Underachievers and Normal Achievers}

efficacy makes a difference in how people feel, think and act. Self-efficacy pertains to optimistic belief about being able to cope with a variety of stressors. Adolescents with high self efficacy choose to perform more challenging and difficult task. In terms of feeling low level of self efficacy is concerned with depression, anxiety and helplessness.

\section{- Well being}

Well being is defined as our happiness, confidence, physical condition and general outlook on life. It is about feeling good and taking care of yourself, responsibilities that can often be neglected when juggling the rigorous demands of everyday living. Well-being is the subjective feelings of contentment, happiness satisfaction with life's experiences and one's performance academically (Martinez \& Dukes 2014)

\section{- $\quad$ Adjustment}

Each day we faced with new situations that demands decisions involve change in both our internal state and our external environment. The process of adjustment involves a person's attempt to cope with master and transcend such challenges. The adjustment of adolescent very much depends on the fulfillment of their significant specific needs that consist of physical needs, emotional needs, social needs, intellectual needs, oral needs and vocational needs. It may be helpful, therefore, to devote a little more space to two important qualities of adjustment. First, it is a process that involves continuous changes and the second people develop consistent pattern of adjustment to these constant changes.

Students make many transitions during their years of schooling: from home to school, middle to high school, and high school to college or work. These transitions are usually major events in the lives of students and parents. The stresses created by these transitions can be minimized when the new environment is responsive to each particular age group.

\section{Objective:}

- To study the locus of control in the underachievers in comparison to the normal achievers.

\section{Hypotheses:}

- It was hypothesized that the underachievers would be higher on external locus of control than the normal achievers.

\section{Sample:}

The sample comprised of 102 students of class tenth from various private schools across the city of Chandigarh. The students belonged to intact middle class families.

\section{Tools:}

The psychological tests used for the present study were:

- $\quad$ Raven’s Standard Progressive Matrices

- $\quad$ Rotter's scale of Locus of Control 


\section{A Comparative Study of Locus of Control in Underachievers and Normal Achievers}

\section{Procedure}

Phase 1: Raven's Standard Progressive Matrices was administered to all the students. Their percentile ranks were recorded. Their academic scores of previous year were recorded and converted into academic percentile ranks. The underachievers and normal achievers were identified in this manner.

Phase 2: Rotter's scale of Locus of Control was administered to underachievers as well as normal achievers .T test was applied to check the significance of difference between the mean scores on locus of control.

\section{Scoring:}

IQ percentiles were recorded using the manual of Raven's Standard Progressive Matrices. Academic scores were converted into percentile ranks using ogive. Those individuals were identified as underachievers, whose IQ percentile exceeded the academic percentile by at least 20 points.

\section{RESULTS}

\begin{tabular}{|c|c|c|}
\hline \multirow{2}{*}{$\begin{array}{c}\text { MEAN SCORE ON LOCUS } \\
\text { OF CONTROL }\end{array}$} & UNDERACHIEVERS & NORMAL ACHIEVERS \\
\cline { 2 - 3 } & 16 & 10 \\
\hline
\end{tabular}

t ratio $=9.09$ significant at 0.01 level

\section{DISCUSSION}

The current study aimed at studying the locus of control in underachievers as compared to normal achievers. The mean score of underachiever group on locus of control was 16 while that of normal achiever group was 10.The difference between means was found to be highly significant. Thus, our hypothesis that underachievers would be higher on externality is supported by the results. In other words we can say that the group of underachievers is more likely to attribute their success or failure to chance factors or to those around them. They do not consider themselves responsible enough for their own actions make lesser effort and thus do not achieve up to their potential.

Underachievement was found to have a prevalence of $20 \%$ among the tenth class students of private schools across the city of Chandigarh that formed the sample of the study. The high prevalence as well as the difference in locus of control can be attributed to the fact that in our country, the child's worth is evaluated in terms of academic achievement because of which a child is pressurized not only to perform well but to do so in some specific subjects that increase his career prospects as a doctor, engineer, IAS, etc. Thus, a lack of interest, coupled with extreme pressures, lead to distasteful performance of tasks, evasion of responsibility and making of external attributions. 


\section{A Comparative Study of Locus of Control in Underachievers and Normal Achievers}

A wide body of research also suggests that underachievers are high on externality. Studies conducted by Heacox (2012) and Mandel and Marcus (2015) reveal that underachievers lack personal responsibility and let others have their control. They lack a connection between their efforts and its outcomes.They fear that their efforts would not pay off and they do not want to take the chance of failing. Anderson \& Hamilton, (2015)

The study has important implications in the field of school counseling. The identification of underachievers from amongst the students is the primary step that counselors need to take. They should also assess the reasons of underachievement in the student before formulating a strategy to tackle the same.

\section{Acknowledgments}

The author appreciates all those who participated in the study and helped to facilitate the research process.

\section{Conflict of Interests}

The author declared no conflict of interests.

\section{REFERENCES}

Anderson, A., Hattie, J. \& Hamilton, R.J. (2015). Locus of Control, Self-Efficacy, and Motivation in Different Schools: Is moderation the key to success?. Educational Psychology, 25(5), 517.

Church, M., Elliot, A.J. \& Gable, S. (2014). Perceptions of classroom environment, achievement goals, and achievement outcomes. Journal of Educational Psychology, 93, 43-54.

Elliot, A. \& McGregor, H. (2012). Text anxiety and the hierarchical model of approach and avoidance achievement motivation. Journal of Personality and Social Psychology, 76, 628-644.

Felton and Briggs (2014) . Adolescent Self-Esteem and Locus of Control: A Longitudinal Study of Gender and Age Differences. Adolescence, 32, 113-130.

Heacox, B.B. (2012). Teacher Locus Of Control: Who's Responsible?. Education, 111(4), 475479.

Larry Smith. (2015). Goal orientations, coping with school failure and school achievement. European Journal of Psychology of Education, 21(1), 53-70.

Mandel, H.P. AND Marcus, S.T. (2015). "Could do better": Why children underachieve and what to do about it. New York : John Wiley and Sons Inc.

Mendol . P. C, \& Marcus (2015). A Pattern Analysis of Students' Achievement Goals, Journal of Educational Psychology, 85(4), 582 - 590.

Mendol . P. C, \& Marcus (2016). Students' goal orientation and cognitive engagement in classroom activities. Journal of Educational Psychology, 80, 514-523. 


\section{A Comparative Study of Locus of Control in Underachievers and Normal Achievers}

Midgley, C., Middleton, M. \& Kaplan, A. (2013). Performanceapproach goals: Good for what, for whom, under what circumstances, and at what cost?. Journal of Educational Psychology, 93, 77-86.

N.Roberts (2016). A social-cognitive approach to motivation and personality. Psychological Review, 95, 256-273.

Rotter, J.B. (1966). Generalized expectancies for internal versus external control of reinforcement .Psychological Monographs, 1.

How to cite this article: T Kaur (2016), A Comparative Study of Locus of Control in Underachievers and Normal Achievers, International Journal of Indian Psychology, Volume 4, Issue 1, No. 69, ISSN:2348-5396 (e), ISSN:2349-3429 (p), DIP:18.01.011/20160401, ISBN:9781-365-45447-9 